\title{
Deep fried wheat chips added with potato peel flour-Effect on quality parameters
}

\author{
Aysun Durmaz ${ }^{1}$, Ferhat Yuksel ${ }^{1,2, *}$ \\ ${ }^{1}$ Food Engineering Department, Faculty of Engineering and Natural Science, Gumushane University, Gumushane, Turkey; \\ ${ }^{2}$ Department of Nutrition and Dietetics, Nigde Omer Halisdemir University, Nigde, Turkey
}

*Corresponding authors: Ferhat Yuksel, Department of Nutrition and Dietetics, Nigde Omer Halisdemir University, Nigde, Turkey. Email: fyuksel@ohu.edu.tr

Submitted: 16 November 2020; Accepted: 29 December 2020; Published: 20 February 2021.

(C) 2021 Codon Publications

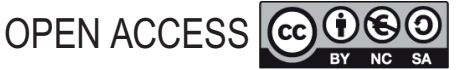

RESEARCH ARTICLE

\begin{abstract}
The aim of this study was to investigate some physicochemical, bioactive, nutritional, and sensory properties of wheat chips enriched with potato peel flour (PPF) at six different concentrations (0, 2, 4, 6, 8, and 10\% w/w). Lipid content of the samples were in the range of 45.57-27.46 g/100 g and lipid content of chips decreased (by $40 \%$ ) significantly $(\mathrm{P}<0.05)$ with the incorporation of PPF. Minimum and maximum hardness levels were $13.32 \mathrm{~kg}$ and $22.64 \mathrm{~kg}$, as determined in the control sample and the chips enriched with $8 \mathrm{~g} / 100 \mathrm{~g}$ PPF, respectively. Total phenolic of the chips was in the range of 364.7-1108.0 $\mathrm{mgGAE} / \mathrm{kg}$ and increased significantly $(\mathrm{P}<0.05)$ with increasing of the PPF. In addition, total dietary fiber content of the samples also increased (by $29 \%$ ) significantly $(\mathrm{P}<0.05)$ by PPF incorporation while the in vitro glycemic index content of samples decreased $(\mathrm{P}<0.05)$. Sensory evaluation revealed that the chips with PPF (by 10\%) were more preferred. In this study, alternative chips were produced using PPF.
\end{abstract}

Keywords: dietary fiber; glycemic index; sensory properties; potato peel and wheat chips

\section{Introduction}

When we look at snacks foods, there are different types of products such as crackers, granola-type bars, chips, and cookies. Among these products, chips are consumed by people of all ages in between regular meals. Globally, there is a huge market for the sale of chips, about \$30-35 billion/year. Consumption of snack foods, such as chips, has been increasing all over and is a prominent constituent of human diet (Kayacier et al., 2014a; McCharthy, 2001; Rababah et al., 2011; Yuksel, 2017). In the recent years, chips producers have been searching for an alternative and novel chips formulation that has functional properties. For that reason, chips are produced using flours such as that of wheat and legumes (Durmaz, 2019; Kayacier et al., 2014a, 2014b; Yuksel, 2017). Also, the chips are fortified by some functional ingredients such as protein, fiber, phenolic compounds, and antioxidants (Izydorczyk et al., 2005; Mendonça et al., 2000).
Recently, there have been a lot of studies about dietary fiber and their use in many food formulations because of their nutrition value (Elkahoui et al., 2018; Kayacier et al., 2014b; Natabirwa et al., 2020; Rios et al., 2020). One of the most popular ingredients used in food formulation is the potato peel. The potato peel has a good nutritional content for health effects in the human diet. The nutrition contents of potato peel are reported to be $17.47 \mathrm{~g} / 100 \mathrm{~g}$ protein, $24.1 \mathrm{~g} / 100 \mathrm{~g}$ total dietary fiber, $6.50 \mathrm{~g} / 100 \mathrm{~g}$ ash, $2878.0 \mathrm{mg}$ $\mathrm{GAE} / \mathrm{kg}$ total phenolic and $3263.8 \mathrm{mgAAE} / \mathrm{kg}$ total antioxidant capacity (Durmaz, 2019). Elkahoui et al. (2018) reported that the potato peels exhibited similar properties as the other dietary fibers and protein in the colon bacteria and so the potato peel must not go to waste. When the potato peel is removed from the potato at households, this valuable product is thrown to the waste bin. Scientists have researched to show the value of the potato peel so as to prevent the throwing of the peels. For example, some foods were enriched with different parts of the potato, 
namely, biscuit enriched with potato peel (Dhingra et al., 2012), bread enriched with potato fiber (Curti et al., 2016), cage fortification with potato fiber (Jeddou et al., 2017), bread enriched with potato peel flour (PPF) (Orr et al., 1982 ) etc. According to our literature survey, there was no study aimed to enrich the wheat chips with potato peel to increase the functionality of the final products.

This study was conducted to investigate the usability of potato peels in deep fried wheat chips. For this purpose, potato belonging to the melody varieties (Solanum tuberosum L.) was taken from a local market and peeled by hand. The peels were then freeze dried, followed by grinding using a blender. PPF was incorporated at different concentrations, that is, 2, 4, 6, 8, and $10 \mathrm{~g} / 100 \mathrm{~g}$ into the dry mix formulation for the production of wheat chips and the chips samples were characterized for their physicochemical, bioactive, nutritional, and sensory properties.

\section{Materials and Methods}

\section{Materials}

Wheat flour (moisture 12.9\%, protein 11.1\%, 0.55\% ash, $2.9 \%$ oil in dry matter, $35 \%$ gluten), potato (Melody type), and salt were sourced from a local market. Corn oil was used for the frying of the chips (Yudum Oil Co. Turkey). The potatoes were sliced at about $1 \mathrm{~mm}$ thickness by hand and then the peels were dried using the freeze-drying (Xianou-12N, China) method for approximately $24 \mathrm{~h}$. Afterward, the dried peels were milled using a blender (Mmr08a1 private collection, $400 \mathrm{~W}$, Gerlingen, Germany) and then sieved (0.500 $\mathrm{mm})$. The PPF was stored at $4{ }^{\circ} \mathrm{C}$ in a refrigerator until analyses.

\section{Preparation of wheat chips and enrichment of samples by potato peel flour}

The production process of the chips was shown as a flow chart in Figure 1. PPF (2, 4, 6, 8, and $10 \mathrm{~g} / 100 \mathrm{~g})$ and salt $(2.0 \mathrm{~g} / 100 \mathrm{~g})$ were incorporated into the dry mix chips formulation. To form the chips dough, wheat flour, PPF, and salt were mixed, as mentioned in Table 1, using a blender (Kitchen Aid, Professional 600 MI, ABD) for a duration of $5 \mathrm{~min}$. Afterward, tap water $(50 \pm 5 \mathrm{~mL})$ was added to the mix and then the mix was kneaded (10 min). At the end of the kneading, the chips dough was covered using a stretch film. Afterward, the dough was kept aside for $30 \mathrm{~min}$ at $25 \pm 2{ }^{\circ} \mathrm{C}$ for suitable hydration. To roll out the chips dough ( $1 \mathrm{~mm}$ thickness), the lab-scale sheeter (Rondo, Doge, Model: SS0615, Switzerland) was used. Corn oil (5 L) was added to the fryer (Mikrotest, Ankara,
Turkey) and the fryer temperature was set to $190^{\circ} \mathrm{C}$. The chips samples were deep fried for $50 \mathrm{~s}$. Finally, the chips samples were taken from the fryer and placed on the paper towel to cool down and then were subjected to the analysis.

\section{Some physicochemical analyses}

Proximate analyses (protein, dry matter, ash, and lipid) were determined per the official procudures (AOAC, 2000). The dry matter was determined by the oven drying method (Nuve FN 120 Turkey). The ash content was determined by the dry burning method using a furnace (Protherm PLF115M, Turkey). The fat content was determined using a Soxhlet extractor system. For ascertaining the protein content of the samples, the Kjeldahl method was used, and the $\mathrm{N}$ content of samples was multiplied by 5.70 for the calculation of total protein level.

\section{Water holding capacity and oil holding capacity of potato peel flour}

Water holding capacity (WHC) and oil holding capacity (OHC) of PPF were analyzed at $25 \pm 2{ }^{\circ} \mathrm{C}$ (room temperature). PPF sample $(0.25 \mathrm{~g})$ was weighed into a $50 \mathrm{~mL}$ screw capped test tube and $10 \mathrm{~mL}$ of distilled water and $10 \mathrm{~mL}$ of oil were added. Afterward, the prepared suspension was mixed using a vortex (1 min). After that, the suspension was centrifuged (Universal 320, Hettich, Germany) at $4100 \mathrm{rpm}$ (10 $\mathrm{min})$. Then, the free water and oil were removed from the suspension. WHC and $\mathrm{OHC}$ were calculated using the following equations (1 and 2). Also, all analyses were replicated with three repetitions (Yuksel and Karaman, 2015).

$$
\begin{aligned}
& \text { WHC }(\mathrm{ml} / \mathrm{g})=\frac{\mathrm{W}_{\text {sediment }}-\mathrm{W}_{\text {sample }}}{\mathrm{W}_{\text {sample }}} \\
& \mathrm{OHC}(\mathrm{ml} / \mathrm{g})=\frac{\mathrm{W}_{\text {sediment }}-\mathrm{W}_{\text {sample }}}{\mathrm{W}_{\text {sample }}}
\end{aligned}
$$

where $\mathrm{W}$ is the weight.

\section{Textural properties}

Within the context of the textural analysis, the hardness of the samples was determined using a texture analyzer (TA.XT Plus, England) equipped with Kramer shear cell attachment (HDP/KS 5). Three chips samples (3 g) (the samples were stored using a zip lock bag after frying for textural analysis) were placed in the cell, and the blade was adjusted to $5 \mathrm{~cm} / \mathrm{min}$. The maximum force, which 


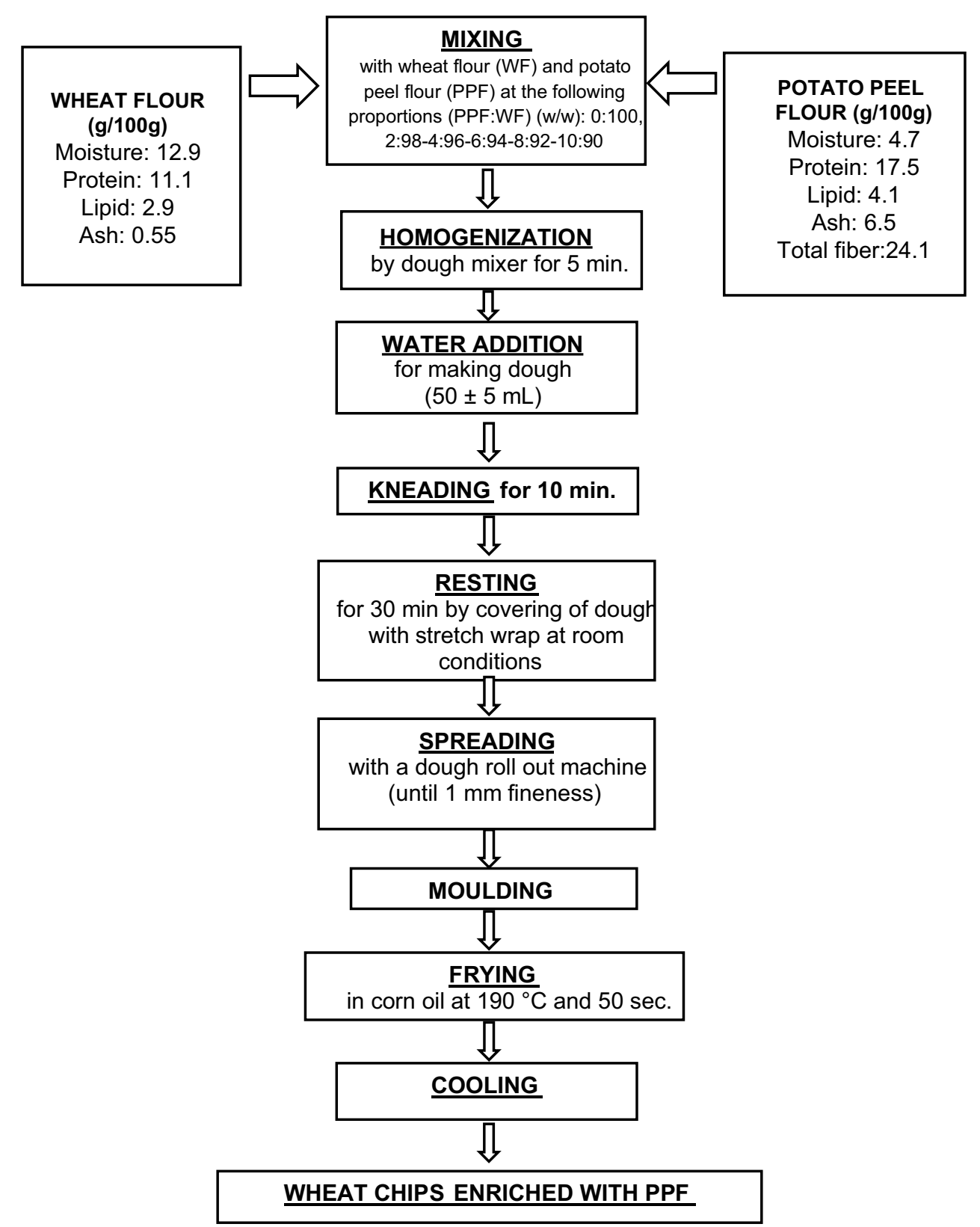

Figure 1. Process flow chart for the production of wheat chips enriched with potato peel flour.

is required to break the sample, was determined by the deformation curve. Seven replicates were done.

\section{Color analysis}

The chips enriched with PPF were manually ground with a mortar and then $L^{*}, \mathrm{a}^{*}$, and $\mathrm{b}^{*}\left[\mathrm{~L}^{*}\right.$ (brightness), a* ( \pm red-green), and $b^{*}$ ( \pm yellow-blue] values were measured by using a colorimeter (Lovibond, England). Ten replicates were performed for each sample.
Determination of total dietary fiber and estimated in vitro glycemic index

To determine the total dietary fiber (TDF) content of chips, the Megazyme TDF assay procedure (K-TDFR$100 \mathrm{~A}$, Ireland) was used.

Glycemic index (GI) analyses (in vitro) were performed according to the method described by Goni et al. (1997). For this, chips samples without oil were milled and then $75 \mathrm{mg}$ of each sample (milled) was weighed into test 
tubes with 10 glass beads. Afterward, $2 \mathrm{~mL} 0.05 \mathrm{M} \mathrm{HCI}$ and $10 \mathrm{mg}$ pepsin were added and then the samples were incubated for $30 \mathrm{~min}$ by using the shaking water bath $\left(37^{\circ} \mathrm{C}\right)$. Ultimately, $4 \mathrm{~mL}, 0.5 \mathrm{M}$ and $\mathrm{pH} 5.2$ sodium asetat buffer solution was incorporated into the each test tubes. The enzyme solution was prepared and stored at $4{ }^{\circ} \mathrm{C}$ during all analyses, and the solution $(1 \mathrm{~mL})$ was added into the each test tubes. Afterward, these mixtures were incubated using a shaking water bath $\left(37^{\circ} \mathrm{C}, 180 \mathrm{~min}\right)$. A $100 \mu \mathrm{L}$ of aliquot was taken from each test tube and placed into the preconditioned eppendorf tube containing $1 \mathrm{~mL}$ ethanol $(50 \%, \mathrm{v} / \mathrm{v})$ during the incubation period. Then, the solutions were centrifuged at $800 \times \mathrm{g}(10 \mathrm{~min})$. Starch digestion rate of each chips sample was calculated to be the percentage of glucose at $10,20,30,60,90,120$, and $180 \mathrm{~min}$. To determine the glucose concentration and the total starch hydrolysis (TSH) content of each sample, a Glucose Kit (D-Glucose Assay Kit, K-GLUC, Megazyme, Ireland) was used (Eq. 3):

$$
\text { TSH }(\%)=\frac{\text { released glucose weight } \times \frac{160}{182}}{\text { total starch weight in chips sample }} \times 100
$$

For the kinetic analysis of starch digestion (in vitro), a nonlinear model $\left(C=C_{\infty}\left(1-\mathrm{e}^{-\mathrm{kt}}\right)\right)$ was used (Goni et $a l ., 1997)$. The starch hydrolyzed at the time $t$ (min) was shown as $\mathrm{C}_{\text {. }} \mathrm{C}_{\infty}$ is the equilibrium \% of starch hydrolyzed after $180 \mathrm{~min}$. The kinetic constant was shown as $\mathrm{k}$. To determine the GI of samples, two replications were conducted. To calculate the hydrolysis index (HI) of each sample, the area below the hydrolysis curve was compared with that of white (stale) bread. The GI of samples was calculated using the following formula (Eq. 4):

$$
\mathrm{GI}=39.71+0.549^{*} \mathrm{HI}
$$

\section{Bioactive analysis of samples}

\section{Total phenolic and flavonoid analyses}

For the preparation of the extracts from the chips samples, $5 \mathrm{~g}$ of chips sample powder and $20 \mathrm{~mL}$ of distilled water were mixed. After this, the mixes was subjected to homogenization for $10 \mathrm{~min}$ and filtrated. The filtrate was used for all bioactive analyses. To determine TPC (Total Phenolic Concentration), a sample $(100 \mu \mathrm{L})$ of $4.5 \mathrm{~mL}$ of deionized water and Folin-Ciocalteu solution $(100 \mu \mathrm{L})$ were mixed by vortex and left at $25 \pm 2{ }^{\circ} \mathrm{C}$ for $10 \mathrm{~min}$. Then, $300 \mu \mathrm{L}$ of $2 \%$ of $\mathrm{Na}_{2} \mathrm{CO}_{3}$ solution was added to the mixture by vortex and then the samples were incubated at $25 \pm 2{ }^{\circ} \mathrm{C}$ for $30 \mathrm{~min}$. At the end of the incubation, the absorbance values of the samples were recorded using a UV-vis spectrophotometer at $760 \mathrm{~nm}$. Gallic acid calibration curve was created for the calculation of the results to be mg GAE/kg (Kasangana et al., 2015).
To determine the TFC (Total Flavonoid Concentration) of the pestil samples, a $500 \mu \mathrm{L}$ of the extract samples and $3200 \mu \mathrm{L}$ of methanol $(30 \% \mathrm{v} / \mathrm{v})$ were mixed together. After that, $150 \mu \mathrm{L}$ of $0.5 \mathrm{M}$ sodium nitrite solution and $150 \mu \mathrm{L}$ of $0.3 \mathrm{M}$ aluminum chloride were added to the mixture using a vortex. Then, $1 \mathrm{~mL}$ of $1 \mathrm{M} \mathrm{NaOH}$ solution was added using the vortex again. All the chips samples were incubated for $10 \mathrm{~min}\left(25 \pm 2{ }^{\circ} \mathrm{C}\right)$. After the incubation, the absorbance values of chips were analyzed using a spectrophotometer (UV-vis) at $506 \mathrm{~nm}$. A Quercetin calibration curve was created for the calculation of the results to be mg QE/kg (Kasangana et al., 2015).

\section{Antioxidant activity}

For the determination of the antioxidant activities of the samples, three different antioxidant analyses, namely, radical scavenging activity (DPPH), phospomolybdenum test, and ferric reducing antioxidant power (FRAP) test were used. In this regard, the DPPH content of the chips was determined according to the modified method of Uysal et al. (2014). A sample $(100 \mu \mathrm{L})$ and DPPH solution $(3000 \mu \mathrm{L}, 0.1 \mathrm{mM}$ in methanol) were mixed by a vortex, and then all the mixes were incubated for 30 min at dark conditions. After the incubation, the absorbance values of the chips were measured using a spectrophotometer (UV-vis, $517 \mathrm{~nm}$ ). The DPPH performance of all the samples was calculated (Eq. 5).

$$
\% \text { inhibition }=\left(\frac{\mathrm{Ac}-\mathrm{As}}{\mathrm{Ac}}\right) \times 100
$$

An ascorbic acid calibration curve was used to calculate the DPPH values (mg AAE/kg).

For the phospomolybdenum analysis, $500 \mu \mathrm{L}$ of the samples and $2500 \mu \mathrm{L}$ of deionized water were mixed by a vortex and then $1000 \mu \mathrm{L}$ of a molybdate reagent was incorporated to this mixture. Afterward, this mixture was mixed well by a vortex for a while and the sample tubes were placed in a water bath at $95{ }^{\circ} \mathrm{C}$ for $90 \mathrm{~min}$ for incubation. After the incubation for about $30 \mathrm{~min}$, the samples were removed from the bath. The antioxidant activity of the chips samples was calculated as ascorbic acid equivalent (AAE) per kilogram of chips samples. (Parmer, 2012).

To determine the ferric reducing antioxidant power (FRAP) test, a sample $(250 \mu \mathrm{L})$ diluted with distilled water and $2750 \mu \mathrm{L}$ of FRAP reagent $(2 \mathrm{~mL} ; 0.01 \mathrm{~mol}$ TPTZ (2,4,6-tripyridyl-s-triazine) in $0.04 \mathrm{~mol} \mathrm{HCl}, 0.02$ mol $\mathrm{FeCl}_{3} \cdot 6 \mathrm{H}_{2} \mathrm{O}$ and $0.3 \mathrm{~mol}$ acetate buffer) water were mixed by a vortex, and then this mixture was incubated for $30 \mathrm{~min}\left(25 \pm 2{ }^{\circ} \mathrm{C}\right)$. Afterward, the absorbance values of the chips were recorded using a spectrophotometer (UV-vis, $593 \mathrm{~nm}$ ). Ferric reducing antioxidant capacity 
of the samples was calculated to be AAE per kilogram of chips samples (Uysal et al., 2014).

\section{Sensory properties of the chips samples}

Twenty panelists (students and lecturers of the Food Engineering Department) evaluated the chips samples using a 9-point scale (1: undesired; 9: desired). The color, crispness, taste/smell, oiliness and overall acceptability of the samples were determined. The samples coded with three-digit numbers were served to the panelists. Between the samples, water was given to the panelists to rinse their mouths (Durmaz, 2019).

\section{Statistical analysis}

To determine the statistically significant data of the chips sample, the SAS version 8.2 software package (SAS 2002, SAS Institute Inc., Cary, NC, USA) was used with the general linear model procedure. Means were divided by ANOVA analysis and statistical significance was denoted by a P-value of 0.05 .

\section{Results and Discussion}

Some properties of PPF are given in Table 1. Dry matter contents of the chips samples were in the range of 96.43$98.62 \%$. The highest dry matter content was found in the samples containing $8 \%$ PPF while the lowest was in the sample containing $4 \%$ PPF. PPF had a significant effect on the dry matter content of the final samples $(\mathrm{P}<0.05$, Table 2). Similar results were reported for bread enriched with potato fiber (Curti et al., 2016). Our results showed that the dry matter content of the chips decreased from a concentration of 0 to $4 \mathrm{~g} / 100 \mathrm{~g}$ PPF, then there was a little increase from 4 to $8 \mathrm{~g} / 100 \mathrm{~g}$ PPF, and then the dry matter showed a decrease again. The main reason for the increases and decreases can be explained with the WHC and $\mathrm{OHC}$ of PPF and the frying conditions. The WHC and $\mathrm{OHC}$ are presented in Table 1. The results obtained showed that the water and oil absorption were determined to be 3.43 and $4.25 \%$, respectively. Jeddou et al. (2017) reported that the WHC and OHC of the PPF were found to be 3.37 and $2.07 \%$, respectively. Other similar results were reported by Dhingra et al. (2012) for biscuits, that is, the oil holding and water retention capacities of the potato peel were determined to be $3.76 \mathrm{~g}$ oil. $\mathrm{g}^{-1}$ fiber and $5.32 \mathrm{~g}$ water. $\mathrm{g}^{-1}$ fiber, respectively. According to the results, the WHC and OHC of PPF in the current study were similar to the literature results.

Significant increases in ash contents of the wheat chips were identified when the amount of PPF was increased
Table 1. Some physicochemical properties of potato peel flour.

\begin{tabular}{lrc} 
Properties & \multicolumn{1}{l}{ Level } & Unit (in dry matter) \\
\hline Dry matter & $95.27 \pm 0.1$ & $\mathrm{~g} / 100 \mathrm{~g}$ \\
Ash & $6.50 \pm 0.1$ & $\mathrm{~g} / 100 \mathrm{~g}$ \\
Lipid & $4.10 \pm 1.0$ & $\mathrm{~g} / 100 \mathrm{~g}$ \\
Protein & $17.47 \pm 0.3$ & $\mathrm{~g} / 100 \mathrm{~g}$ \\
Total phenolic & $2878.0 \pm 96.6$ & $\mathrm{mg} \mathrm{GAE} / \mathrm{kg}$ \\
Total antioxidant & $3263.8 \pm 12.4$ & $\mathrm{mg} \mathrm{AAE} / \mathrm{kg}$ \\
Total dietary fiber & $24.1 \pm 0.28$ & $\mathrm{~g} / 100 \mathrm{~g}$ \\
Water holding capacities & $3.43 \pm 2.0$ & $\%$ \\
Oil holding capacities & $4.25 \pm 0.5$ & $\%$ \\
$\mathrm{~L}^{*}$ & $68.46 \pm 1.1$ & \\
$\mathrm{a}^{*}$ & $3.34 \pm 0.6$ & \\
$\mathrm{~b}^{*}$ & $29.09 \pm 1.1$ & \\
\hline
\end{tabular}

in the formulation $(\mathrm{P}<0.05$, Table 2$)$. As can be seen from Table 1, the ash content of PPF was $6.50 \mathrm{~g} / 100 \mathrm{~g}$. Similar results were reported by Dhingra et al. (2012) for biscuits, that is, the total ash content of the potato peel was found to be $5.31 \%$. Ash contents of the wheat chips varied from 1.01 to $1.67 \mathrm{~g} / 100 \mathrm{~g}$. Therefore, the main cause for the higher amount of ash with the adding of PPF could be the fact that PPF is rich in minerals. Similar results were reported by Dhingra et al. (2012) for biscuits, that is, the total ash content of the sample was measured as a: $0.81,1.26,1.36$, and $1.38 \mathrm{~g} / 100 \mathrm{~g}$ for biscuits prepared using $0,5,10$, and $15 \mathrm{~g} / 100 \mathrm{~g}$ potato peel fiber, respectively.

Significant decreases in the lipid contents of wheat chips were identified when the amount of PPF was increased in the formulation $(P<0.05$, Table 2$)$. Lipid contents of the wheat chips varied from 45.57 to $27.46 \mathrm{~g} / 100 \mathrm{~g}$. The lipid contents of the chips were found to have decreased by $40 \%$ when $10 \%$ of PPF was included in the recipe. The first main cause of decreased lipid content with the increasing of PPF in the formulation of samples might be that PPF acts as a coating matter which occasioned the formation of lesser pores and so less lipids were taken up during the frying process. The second main reason can be that protein content of PPF act as a covering matter and then so less lipid were taken up during the frying process. Dhingra et al. (2012) reported that the lipid contents of the biscuits were found to be 24.15-20.75-19.05 and $19.00 \%$ for biscuits produced by using 0, 5, 10 and $15 \%$ PPF, respectively. These results and the results of our lipid analyses showed that the lipid content of the samples can be decreased with the addition of potato peel fiber.

Significant increases were also observed in the protein contents of the chips samples when PPF was added $(\mathrm{P}<$ 0.05 , Table 2). Maximum protein content (9.15 g/100g) 
Table 2. Some physicochemical and color properties of the samples.

\begin{tabular}{|c|c|c|c|c|c|c|c|c|}
\hline Sample & $\begin{array}{l}\text { Dry matter } \\
(\mathrm{g} / 100 \mathrm{~g})\end{array}$ & $\begin{array}{c}\text { Ash } \\
(\mathrm{g} / 100 \mathrm{~g})\end{array}$ & $\begin{array}{l}\text { Lipid } \\
(\mathrm{g} / 100 \mathrm{~g})\end{array}$ & $\begin{array}{l}\text { Protein } \\
(\mathrm{g} / 100 \mathrm{~g})\end{array}$ & $\begin{array}{l}\text { Hardness } \\
(\mathrm{kg})\end{array}$ & $L^{*}$ & $a^{*}$ & $b^{*}$ \\
\hline 1 & $97.93 \pm 0.2^{b}$ & $1.01 \pm 0.0^{c}$ & $45.57 \pm 1.2^{\mathrm{a}}$ & $7.47 \pm 0.2^{b}$ & $13.32 \pm 3.2^{b}$ & $68.47 \pm 1.1^{\mathrm{a}}$ & $3.34 \pm 0.6^{c}$ & $29.09 \pm 1.1^{b}$ \\
\hline 2 & $96.62 \pm 0.1^{\mathrm{c}}$ & $1.21 \pm 0.0^{\mathrm{bc}}$ & $38.60 \pm 1.3^{b}$ & $7.44 \pm 0.5^{b}$ & $17.04 \pm 1.0^{\mathrm{ab}}$ & $65.66 \pm 1.1^{\mathrm{a}}$ & $3.44 \pm 0.4^{c}$ & $28.07 \pm 0.4^{b}$ \\
\hline 3 & $96.43 \pm 0.4^{c}$ & $1.23 \pm 0.2^{\mathrm{bc}}$ & $39.13 \pm 0.6^{b}$ & $8.53 \pm 0.3^{a}$ & $17.04 \pm 2.1^{\mathrm{ab}}$ & $57.83 \pm 2.0^{b}$ & $5.84 \pm 0.7^{b}$ & $28.75 \pm 2.4^{b}$ \\
\hline 4 & $98.55 \pm 0.1^{\mathrm{a}}$ & $1.51 \pm 0.1^{\mathrm{ab}}$ & $39.07 \pm 0.7^{b}$ & $8.43 \pm 0.1^{\mathrm{a}}$ & $21.41 \pm 2.4^{\mathrm{a}}$ & $54.77 \pm 1.8^{b}$ & $7.74 \pm 0.2^{\mathrm{a}}$ & $31.54 \pm 0.7^{\mathrm{a}}$ \\
\hline 5 & $98.62 \pm 0.1^{\mathrm{a}}$ & $1.45 \pm 0.2^{\mathrm{ab}}$ & $35.44 \pm 0.3^{c}$ & $9.05 \pm 0.6^{\mathrm{a}}$ & $22.64 \pm 5.3^{\mathrm{a}}$ & $56.45 \pm 3.1^{\mathrm{b}}$ & $7.90 \pm 0.8^{\mathrm{a}}$ & $32.66 \pm 1.4^{a}$ \\
\hline 6 & $97.87 \pm 0.0^{\mathrm{b}}$ & $1.67 \pm 0.2^{\mathrm{a}}$ & $27.46 \pm 1.6^{\mathrm{d}}$ & $9.15 \pm 0.0^{\mathrm{a}}$ & $19.46 \pm 3.5^{\mathrm{a}}$ & $55.64 \pm 2.2^{b}$ & $7.22 \pm 0.4^{\mathrm{a}}$ & $31.55 \pm 0.5^{\mathrm{a}}$ \\
\hline
\end{tabular}

a-d: Different superscript letters in the same column indicate significant difference $(P<0.05), 1$ : Control group.

was designated for the sample containing $10 \mathrm{~g} / 100 \mathrm{~g}$ of PPF while the minimum lipid content $(7.44 \mathrm{~g} / 100 \mathrm{~g})$ was determined for the samples containing $2 \mathrm{~g} / 100 \mathrm{~g}$ of PPF, and the increment of protein was about $17 \mathrm{~g} / 100 \mathrm{~g}$. Also, the protein content of PPF was $17.47 \mathrm{~g} / 100 \mathrm{~g}$ (Table 1). Similar results were reported by Jeddou et al. (2017) for cake that is, the protein content of the potato peel powder was found to be $15.71 \mathrm{~g} / 100 \mathrm{~g}$. Other similar results were reported by Choi et al. (2016) for potato peels that the protein content of the potato peels were determined to be from 9.51 to $10.6 \mathrm{~g} / 100 \mathrm{~g}$.

The highest instrumental hardness value was measured $(22.64 \mathrm{~kg})$ in the chips containing $8 \mathrm{~g} / 100 \mathrm{~g}$ of PPF. However, the lowest instrumental hardness was detected $(13.32 \mathrm{~kg})$ in PPF-free chips sample. The hardness content of samples was significantly affected from the addition of PPF $(\mathrm{P}<0.05$, Table 2$)$. There was a significant increase between control sample (first sample) and others $(P<0.05)$, but there was no significant change from the second sample to the sixth sample $(\mathrm{P}>0.05$, Table 2). Nevertheless, for the hardness content of samples, there was about $5 \mathrm{~kg}$ difference between the second and the fifth sample. According to the panelist, there was a significant difference between the second and the sixth sample $(\mathrm{P}<0.05)$. The instrumental hardness and sensory firmness results showed that wheat chips can be made using $10 \mathrm{~g} / 100 \mathrm{~g}$ of PPF. Instrumental hardness and sensory firmness are very important quality variables in snack products such as chips. Snack food such as chips should be firm enough to resist cracking throughout processing and within the package until it reaches the consumer. Also, these products should be crisp when they are consumed (Yuksel and Kayacier, 2016). Pęksa et al. (2010) reported that the hardness content of the snacks enriched with wheat bran, corn bran, and corn germ at different concentrations $(0-10 \%)$ changed significantly.

Color values of the samples $\left(L^{*}, a^{*}\right.$, and $\left.b^{*}\right)$ showed significant changes with the addition of PPF into the chips recipe $(\mathrm{P}<0.05$, Table 2$)$. Maximum lightness $\left(\mathrm{L}^{*}\right)$ level
(68.47) was determined for the control sample $(0 \mathrm{~g} / 100 \mathrm{~g}$ PPF) while the minimum lightness value (54.77) was recorded for the wheat chips sample containing $6 \mathrm{~g} / 100 \mathrm{~g}$ of PPF. Wheat chips redness ( $\mathrm{a}^{*}$ ) levels varied from 3.34 to 7.90. The yellowness levels of chips samples ranged from 28.07 to 32.66. The instrumental color properties of PPF were found to be $68.46\left(\mathrm{~L}^{*}\right), 3.34\left(\mathrm{a}^{*}\right)$, and $29.09\left(\mathrm{~b}^{*}\right)$. The instrumental color properties of the chips samples were affected by PPF color properties. Also, the frying time and temperature did not change during frying and so the changes of color properties of the final samples were affected by PPF color. Similar results were reported by Jeddou (2017) for cake, that is, the lightness values of the cake samples decreased while the redness and yellowness increased with the increasing of PPF. The other similar results were reported by Kayacier et al. (2014b) for wheat chips enriched with apple fiber in which the lightness values of the samples decreased with the increasing of the fiber level.

Phenolic contents of the samples were found to be linearly increased with PPF incorporation $(\mathrm{P}<0.05$, Table 3). As is seen in Table 1, the total phenolic of PPF was measured to be $2878.0 \mathrm{mgGAE} / \mathrm{kg}$. Total phenolic of the samples was determined in the range of 364.7 and $1108.0 \mathrm{mgGAE} / \mathrm{kg}$ (Table 3). The main TPC of potato peel was determined as chlorogenic acid, neochlorogenic acid and cryptochlorogenic acid (approximately 90\%) (Wu, 2016). The TFC of the samples were determined in the range of 414.7 and $813.4 \mathrm{mgQE} / \mathrm{kg}$ (Table 3). There was a linear increase in the total antioxidant capacities of the sample with the addition of PPF from the control sample (first sample) to the sixth sample. The antioxidant capacities of the samples were measured to be 842.5 , 1165.0, 1283.8, 1978.8, 1757.5, and $2070.0 \mathrm{mg} \mathrm{AAE} /$ $\mathrm{kg}$ for chips produced by using $0,2,4,6$, and $8 \mathrm{~g} / 100 \mathrm{~g}$ PPF, respectively. The change in the total antioxidant capacities of the chips sample was found to be significant $(\mathrm{P}<0.05$ Table 3$)$. As is seen in Table 1 , the total antioxidant capacities of PPF were found to be $3263.8 \mathrm{mg}$ $\mathrm{AAE} / \mathrm{kg}$. Also, there was a linear increase in the DPPH 
Table 3. Some bioactive properties, hydrolysis index (HI), estimated glycemic index (eGI) and total dietary fiber (TDF) contents of the chips samples.

\begin{tabular}{|c|c|c|c|c|c|c|c|c|}
\hline Sample & $\begin{array}{c}\text { Total } \\
\text { phenolic } \\
\text { (mg GAE/kg) }\end{array}$ & $\begin{array}{c}\text { Total } \\
\text { flavonoid } \\
\text { (mg QE/kg) }\end{array}$ & $\begin{array}{c}\text { Total } \\
\text { antioxidant } \\
\text { (mg AAE/kg) }\end{array}$ & $\begin{array}{c}\text { FRAP } \\
\left(\mathrm{mg} \mathrm{FeSO}_{4} / \mathrm{kg}\right)\end{array}$ & $\begin{array}{c}\text { DPPH } \\
\text { (mg AAE/kg) }\end{array}$ & HI & eGI & $\begin{array}{c}\text { TDF } \\
(\mathrm{g} / 100 \mathrm{~g})\end{array}$ \\
\hline 1 & $364.7 \pm 4.7^{\mathrm{e}}$ & $574.2 \pm 90.2^{c}$ & $842.5 \pm 0.1^{d}$ & $3587.5 \pm 53.0^{d}$ & $200.0 \pm 7.1^{\mathrm{d}}$ & $97.2 \pm 1.0^{\mathrm{a}}$ & $93.1 \pm 0.5^{\mathrm{a}}$ & $4.8 \pm 1.1^{\mathrm{ab}}$ \\
\hline 2 & $519.3 \pm 0.0^{d}$ & $414.7 \pm 45.1^{c}$ & $1165.0 \pm 102.5^{c}$ & $4212.5 \pm 100.2^{d}$ & $162.5 \pm 3.5^{\mathrm{d}}$ & $95.0 \pm 1.0^{b}$ & $92.0 \pm 0.3^{b}$ & $4.0 \pm 0.1^{b}$ \\
\hline 3 & $710.5 \pm 32.0^{c}$ & $606.1 \pm 90.2^{b c}$ & $1283.8 \pm 8.8^{c}$ & $7170.9 \pm 182.7^{c}$ & $230.0 \pm 14.1^{c d}$ & $95.0 \pm 0.1^{b}$ & $91.8 \pm 0.1^{b}$ & $5.0 \pm 1.0^{a b}$ \\
\hline 4 & $1108.0 \pm 2.4^{a}$ & $510.2 \pm 0.1^{c}$ & $1978.8 \pm 274.0^{\mathrm{ab}}$ & $13775.0 \pm 82.5^{a}$ & $292.5 \pm 3.5^{c}$ & $89.0 \pm 0.1^{d}$ & $88.6 \pm 0.1^{d}$ & $5.1 \pm 1.4^{\mathrm{ab}}$ \\
\hline 5 & $1008.0 \pm 11.8^{b}$ & $813.4 \pm 22.6^{a}$ & $1757.5 \pm 46.0^{\mathrm{b}}$ & $12062.5 \pm 783.7^{b}$ & $582.5 \pm 60.1^{b}$ & $92.3 \pm 1.4^{c}$ & $90.4 \pm 1.0^{c}$ & $5.5 \pm 1.0^{a b}$ \\
\hline 6 & $1107.2 \pm 34.2^{\mathrm{a}}$ & $797.4 \pm 135.3^{\mathrm{ab}}$ & $2070.0 \pm 3.5^{\mathrm{a}}$ & $14570.8 \pm 17.7^{a}$ & $672.5 \pm 53.0^{a}$ & $88.3 \pm 0.2^{d}$ & $88.2 \pm 0.1^{d}$ & $6.9 \pm 0.2^{\mathrm{a}}$ \\
\hline
\end{tabular}

a-d: Different superscript letters in the same column indicates significant difference $(P<0.05)$. 1: Control group.

(1,1-diphenyl-2-picrylhydrazyl) and FRAP analysis results with the addition of PPF. Maximum $\mathrm{DPPH}$ value was $672.5 \mathrm{mg} \mathrm{AAE} / \mathrm{kg}$ in the 6th sample that contains 10 $\mathrm{g} / 100 \mathrm{~g}$ of PPF while minimum DPPH value was 162.5 $\mathrm{mg} \mathrm{AAE} / \mathrm{kg}$ in the second sample. The highest FRAP value was $14570.8 \mathrm{mgFeSO}_{4} / \mathrm{kg}$ in sixth sample while the lowest FRAP value was $3587.5 \mathrm{mgFeSO}_{4} / \mathrm{kg}$ in the control sample (contain $0 \mathrm{~g} / 100 \mathrm{~g}$ PPF). Recently, in more studies, a significant positive correlation was observed between the antioxidant capacity and the total phenolic of potato peel (Sampaio et al., 2020). The phenolic compounds of potato peel are mainly chlorogenic, caffeic, and ferulic acids, and the peel is a well-known source of these acids and can be effectively used as strong antioxidants in human nutrition (Singh et al., 2020). Similar results were reported by Singh and Rajini (2004) for potato peel extract that the DPPH scavenging activity of the samples increased depending on the potato peel extract amount from $0 \mathrm{mg}$ to $5 \mathrm{mg}$. Potato peel has a high content of polyphenols and so it is considered to be a natural antioxidant in the food system. Thus, the influential usage of the potato peel as an antioxidant material in the food system has been investigated widely (Al-Weshahy and Rao, 2012).

Total dietary fiber content of the control sample (in PPF without chips) was $4.8 \mathrm{~g} / 100 \mathrm{~g}$, while the sixth sample (10 $\mathrm{g} / 100 \mathrm{~g}$ PPF in the chips) had $6.9 \mathrm{~g} / 100 \mathrm{~g}$ (Table 3). This shows that the dietary fiber level of the samples increased by $29 \%$ when $10 \mathrm{~g} / 100 \mathrm{~g}$ of PPF was included. As is seen from Table 1, the total dietary fiber of PPF was 24.1 $\mathrm{g} / 100 \mathrm{~g}$. Therefore, the main reason for the higher total dietary fiber content with the increasing of PPF could be the fact that PPF is rich in total dietary fiber. Potato peel waste is a good source of dietary fiber and the average dietary fiber content of potato peel waste was $40 \mathrm{~g} / 100 \mathrm{~g}$, and the rate of dietary fiber can change according to the peeling method (Al-Weshahy and Rao, 2012; Sepelev and
Galoburda, 2015). Potato peel waste has a high dietary fiber source and it can be utilized in the manufacture of healthy and functional food (Sepelev and Galoburda, 2015).

The HI content ranged from 97.2 to 88.3 , and the lowest value was found in the sixth sample containing $10 \mathrm{~g} / 100 \mathrm{~g}$ of PPF (Table 3 and Figure 2). Also, the same result was found in the estimated GI content. The in vitro estimated GI values (eGI) ranged from 88.2 to 93.1 , and the lowest value was found in the sixth sample containing $10 \mathrm{~g} / 100 \mathrm{~g}$ of PPF. The eGI of the samples significantly decreased with the increasing of PPF in the chips formulation $(\mathrm{P}<0.05$, Table 3). When the total dietary fiber increased in the recipe, the eGI decreased and so the results can be associated. Brand-Miller et al. (2002) investigated the GI level of the intensive dietary fibers and food, and found that the natural cell wall architecture that remains untouched in general have lower GIs. Lightowler and Henry (2009) reported a significant reduction in the eGI values of mashed potato samples enriched with dietary fiber.

Sensory analyses revealed that PPF addition did not impact the overall sensory acceptability of the samples (P > 0.05, Table 4), suggesting that $10 \mathrm{~g} / 100 \mathrm{~g}$ of PPF content can be used without impacting consumer acceptability of the chips. Similar results were reported by Orr et al. (1982) for bread enriched with potato peel (with 5 and $15 \%$ peel), that is, the overall rate scores in sensory analyses of the samples were not significantly different. El-Anany et al. (2007) reported that the best formulation of chicken enriched with rusk and potato peel powder was found to be $25: 75$ and 50:50\%, respectively, and these results showed that potato peel powder could be used as a coating matter in these food items. Potato peel waste can be utilized in bakeries as a substitute material for $10 \%$ of wheat flour without changes in sensory acceptability (Sepelev and Galoburda, 2015). 

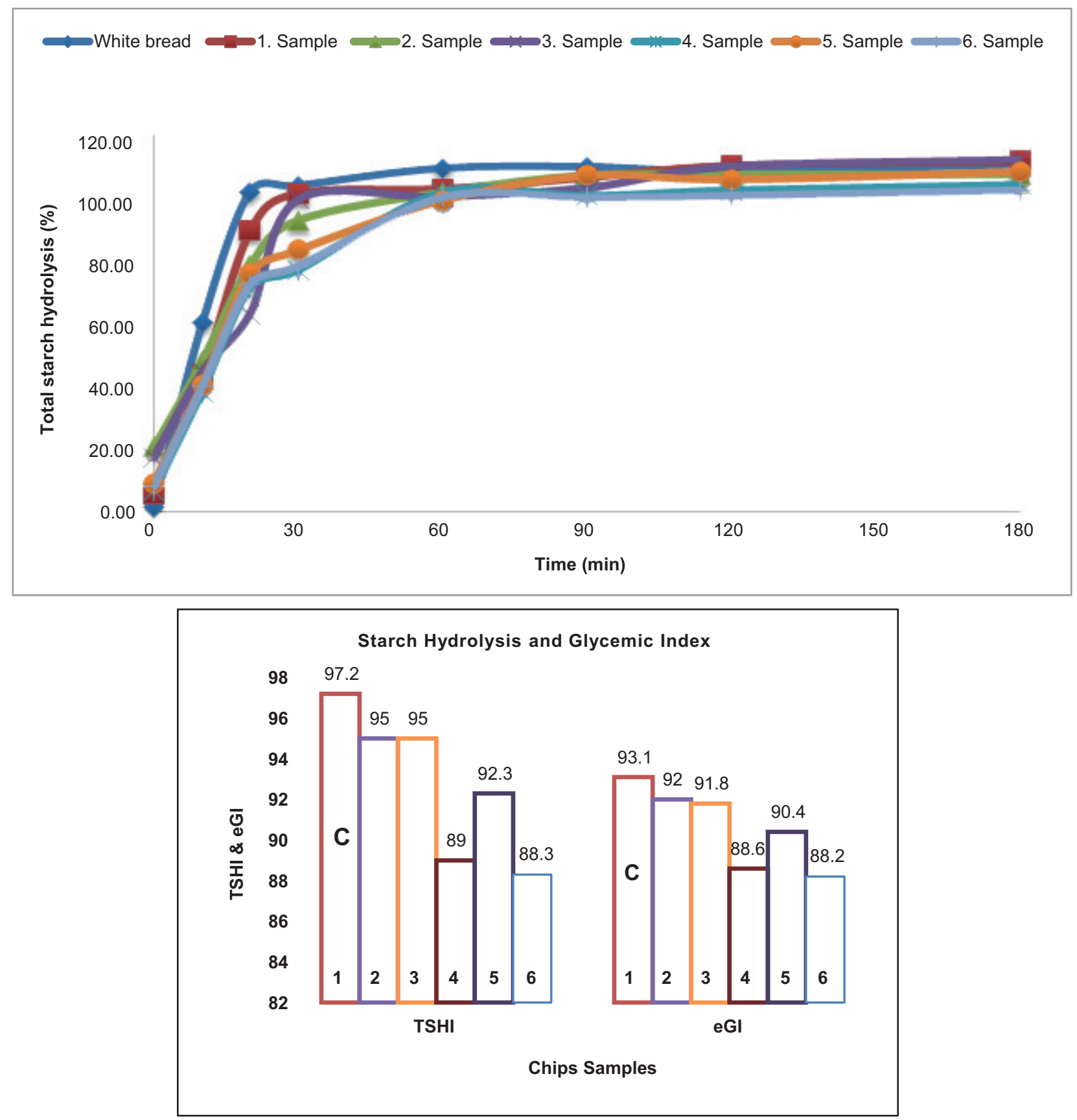

Figure 2. Total starch hydrolysis curves and eGI values of the chips samples

Table 4. Sensory properties of the chips samples.

\begin{tabular}{|c|c|c|c|c|c|}
\hline Sample & Color & Firmness & Taste/smell & Oiliness & Overall acceptability \\
\hline 1 & $5.75 \pm 2.2^{\mathrm{a}}$ & $5.90 \pm 1.6^{\mathrm{ab}}$ & $4.70 \pm 2.1^{a}$ & $4.90 \pm 1.9^{\mathrm{ab}}$ & $5.30 \pm 2.4^{a}$ \\
\hline 2 & $5.30 \pm 2.2^{\mathrm{a}}$ & $5.35 \pm 2.1^{b}$ & $4.25 \pm 1.9^{a}$ & $4.20 \pm 2.2^{b}$ & $4.95 \pm 1.9^{a}$ \\
\hline 3 & $5.10 \pm 2.0^{\mathrm{a}}$ & $6.55 \pm 1.9^{\mathrm{ab}}$ & $5.20 \pm 2.4^{\mathrm{a}}$ & $5.60 \pm 2.3^{\mathrm{ab}}$ & $5.45 \pm 1.5^{\mathrm{a}}$ \\
\hline 4 & $5.80 \pm 1.8^{\mathrm{a}}$ & $6.15 \pm 2.3^{\mathrm{ab}}$ & $5.20 \pm 2.4^{a}$ & $4.85 \pm 2.3^{\mathrm{ab}}$ & $5.35 \pm 2.1^{\mathrm{a}}$ \\
\hline 5 & $4.95 \pm 1.8^{\mathrm{a}}$ & $6.15 \pm 2.2^{\mathrm{ab}}$ & $5.20 \pm 2.3^{a}$ & $4.85 \pm 2.5^{\mathrm{ab}}$ & $5.35 \pm 1.8^{a}$ \\
\hline 6 & $5.65 \pm 1.6^{a}$ & $6.90 \pm 1.5^{\mathrm{a}}$ & $5.25 \pm 1.9^{a}$ & $5.90 \pm 1.4^{\mathrm{a}}$ & $5.60 \pm 2.1^{\mathrm{a}}$ \\
\hline
\end{tabular}

a-b: Different superscript letters in the same column indicates significant difference $(P<0.05) .1$ : Control group. 


\section{Conclusion}

Wheat chips were enriched with PPF to develop a healthy snack product. The addition of PPF to the wheat chips dough reduced the lipid absorption while it increased the total dietary fiber, phenolic compounds and antioxidant content of the resultant product. The quality of chips was acceptable up to $10 \%$ replacement of wheat flour with PPF. Wheat chips enriched with PPF has the potential to be commercialized as a healthy snack.

\section{Acknowledgment}

This study was derived from the post-graduate thesis of Aysun Durmaz. The authors would like to thank the Food Science Department of Gumushane University for their laboratory equipment support. We also would like to thank to Dr. Cemalettin BALTACI for his assistance in phenolic and antioxidant analysis of the samples.

\section{References}

Al-Weshahy, A. and Rao, V.A., 2012. Potato peel as a source of important phytochemical antioxidant nutraceuticals and their role in human health-a review. In: Phytochemicals as nutraceuticals-global approaches to their role in nutrition and health, Edited by Venketeshwer Rao, University of Toronto, Intechopen, 207-225. https://doi.org/10.5772/30459

AOAC., 2000. Analyses code 990.03, In official methods of analysis of AOAC International. Washington DC: Assoc Off Anal Chem, 17th Ed. 1(4): 26-27.

Brand-Miller, J.C.S., Dorota, H.A.H., Pawlak, B. and McMillan, J., 2002. Glycemic index and obesity. American Journal of Clinical Nutrition 76: 281-285. https://doi.org/10.1093/ajcn/76.1.281S

Choi, S.H., Kozukue, N., Kim, H.J. and Friedman, M.N., 2016. Analysis of protein amino acids, non-protein amino acids and metabolities, dietary protein, glucose, fructose, sucrose, phenolic and flavonoid content and antioxidative properties of potato tubers, peels and cortexe (pulps). Journal of Food Composition and Analysis 50: 77-87. https://doi.org/10.1016/j.jfca.2016.05.011

Curti, E., Carini, E., Diantom, A. and Vittadini, E., 2016. The use of potato fibre to improve bread physico-chemical properties during storage. Food Chemistry 195: 64-70. https://doi. org/10.1016/j.foodchem.2015.03.092

Dhingra, D., Michael, M. and Rajput, H., 2012. Physico-chemical characteristics of dietary fibre from potato peel and its effect on organoleptic characteristics of biscuits. Journal of Agricultural Engineering 49(4): 25-32.

Durmaz, A., 2019. Utilization of potato peel (domestic waste) in deep oil fried wheat chips. MS thesis, Gümüşhane University, The Graduate School of Natural and Applied Sciences, Department of Food Engineering, 76 p.

El-Anany, A.M. and Rehab, F.M.A., 2007. Effect of mixing rusk with various levels of potato peel powder during frying and storage processes. Electronic Journal of Environmental, Agricultural and Food Chemistry 6(2): 1828-1837.

Elkahoui, S., Bartley, G.E., Yokoyama, W.H. and Friedman, M. 2018. Dietary Supplementation of Potato Peel Powders Prepared from Conventional and Organic Russet and Non-organic Gold and Red Potatoes Reduces Weight Gain in Mice on a High-Fat Diet. Journal of Agriculture and Food Chemistry, 66, 6064-6072. https://doi.org/10.1021/acs.jafc.8b01987

Goni, I., Garcia-Alonso, A. and Saura-Calixto, F., 1997. A starch hydrolysis procedure to estimate glycemic index. Nutritional Research 17: 427-437. https://doi.org/10.1016/S0271-5317(97)00010-9

Izydorczyk, M.S., Lagasse, S.L., Hatcher, D.W., Dexter, J.E. and Rossnagel, B.G., 2005. The enrichment of Asian noodles with fiber-rich fractions derived from roller milling of hull-less barley. Journal of the Science of Food and Agriculture 85: 20942104. https://doi.org/10.1002/jsfa.2242

Jeddou, K.B., Bouaziz, F., Zouari-Ellouzi, S., Chaari, F., EllouzChaabouni, S., Ellouz-Ghorbel, R., et al., 2017. Improvement of texture and sensory properties of cakes by addition of potato peel powder with high level of dietary fiber and protein. Food Chemistry 217: 668-677. https://doi.org/10.1016/j. foodchem.2016.08.081

Kasangana, P., Haddad, P.S. and Stevanovic, T., 2015. Study of polyphenol content and antioxidant capacity of myrianthus arboreus (Cecropiaceae) root bark extracts. Antioxidants 4(2): 410-426. https://doi.org/10.3390/antiox4020410

Kayacier, A., Yüksel, F. and Karaman, S., 2014b. Response surface methodology study for optimization of effects of fiber level, frying temperature, and frying time on some physicochemical, textural, and sensory properties of wheat chips enriched with apple fiber. Food and Bioprocess Technology 7: 133-147. https://doi. org/10.1007/s11947-013-1096-6

Kayacier, A., Yuksel, F. and Karaman, S., 2014a. Simplex lattice mixture design approach on physicochemical and sensory properties of wheat chips enriched with different legume flours: an optimization study based on sensory properties. LWT-Food Science and Technology 58: 639-648. https://doi.org/10.1016/j. lwt.2014.03.032

Lightowler, H.J. and Henry, C.J.K., 2009. Glycemic response of mashed potato containing high-viscosity hydroxypropylmethylcellulose. Nutrition Research 29(8): 551-557. https://doi. org/10.1016/j.nutres.2009.06.004

McCarthy, A.J., 2001. The snack industry: history, domestic andglobal status, in Snack Foods Processing,ed.byLusasWEand Rooney WL, Technomic Publishing, Pennsylvania,pp. 29-35. https://doi.org/10.1201/9781420012545.ch2

Mendonça, S., Grossmann, M.V.E. and Verhe, R., 2000. Corn bran as a fiber source in expanded snacks. LWT- Food Science and Technology 33: 2-8. https://doi.org/10.1006/fstl.1999.0601

Natabirwa, H., Nakimbugwe, D., Lung'aho, M., Tumwesigye, K.S. and Muyonga, J.H., 2020. Bean-based nutrient-enriched puffed snacks: formulation design, functional evaluation, and optimization. Food Science \& Nutrition 8: 4763-4772. https://doi. org/10.1002/fsn3.1727

Parmer, S.M., 2012. Preliminary investigation of Herniaria Incana Lam. Determination of the total flavonoid content, antioxidant 
properties and free radical scavenging capacity. Master's thesis, The University of Bergen, 78 p.

Pęksa, A., Miedzianka, J., Kita, A., Tajner-Czopek, A. and Rytel, E., 2010. The quality of fried snacks fortified with fiber and protein supplements. Potravinárstvo 2: 59-64. https://doi. org/10.5219/54

Orr, P.H., Toma, R.B., Munson, S.T. and D'Appolonia, B., 1982. Sensory evaluation of breads containing various levels of potato peel. American Potato Journal 59: 605-611. https://doi. org/10.1007/BF02867600

Rababah, T.M., Yücel, S., Ereifej, K.I., Alhamad, M.N., Al-Mahasneh, M.A., Yang, W., et al., 2011. Effect of grape seed extracts on the physicochemical and sensory properties of corn chips during storage. Journal of the American Oil Chemists Society 88: 631-637. https://doi.org/10.1007/s11746-010-1709-4

Rios, M.B., Iriondo-DeHond, A., Iriondo-DeHond, M., Herrera, T., Velasco, D., Gómez-Alonso, S., et al., 2020. Effect of coffee cascara dietary fiber on the physicochemical, nutritional and sensory properties of a gluten-free bread formulation. Molecules 25: 1358. https://doi.org/10.3390/molecules 25061358

Sampaio, S.L., Petropoulos, S.A., Alexopoulos, A., Heleno, S.A., Santos-Buelga, C., Barros, L., et al., 2020. Potato peels as sources of functional compounds for the food industry: a review. Trends Food Science and Technology 103: 118-129. https://doi. org/10.1016/j.tifs.2020.07.015

Sepelev, I. and Galoburda, R., 2015. Industrial potato peel waste application in food production: a review. Research for Rural Development 1: 130-136.

Singh, B., Singh, J., Singh, J.P., Kaur, A. and Singh, N., 2020. Phenolic compounds in potato (Solanum tuberosum L.) peel and their health-promoting activities. International Journal of Food Science and Technology 55: 2273-2281. https://doi.org/10.1111/ ijfs. 14361

Singh, N. and Rajini, P.S., 2004. Free radical scavenging activity of an aqueous extract of potato peel. Food Chemistry 85: 611-616. https://doi.org/10.1016/j.foodchem.2003.07.003

Uysal, A., Güneş, E., Aktümsel, A. and Durak, Y., 2014. Hyoscyamus Reticulatus'un Hekzan ve Su Özütlerinin Antioksidan ve Antimikrobiyal Özellikleri Üzerine Bir Çalışma, Selçuk Üniversitesi Fen Fakültesi Fen Dergisi 39: 21-29.

Wu, D., 2016. Recycle technology for potato peel waste processing: a review. Procedia Environmental Sciences 31: 103-107. https:// doi.org/10.1016/j.proenv.2016.02.014

Yuksel, F., 2017. Effect of powder of macaroni boiling water (by-product) on textural, oil uptake, physico-chemical, sensory and morphological properties of fried wheat chips. Journal of Food Measurement 11: 290-298. https://doi.org/10.1007/ s11694-016-9396-y

Yuksel F. and Karaman K., 2015. Utilization of macaroni by-product as a new food ingredient: Powder of macaroni boiling water. LWT - Food Science and Technology, 63 (2), 1063-1068. https:// doi.org/10.1016/j.lwt.2015.03.099

Yuksel, F. and Kayacier, A., 2016. Utilization of stale bread in fried wheat chips: response surface methodology study for the characterization of textural, morphologic, sensory, some physicochemical and chemical properties of wheat chips. LWT-Food Science and Technology 67: 89-98. https://doi.org/10.1016/j. lwt.2015.11.029 